\title{
Phytochemical study, antiplasmodial activity and acute toxicity of the aqueous extract of the stem bark of Alstonia boonei De Wild
}

\author{
Hermeline Ntalani $^{1 *}$, Mon-Sang César Akouala Bouanga ${ }^{1}$, Gelase Fredy Nsonde Ntandou ${ }^{3,4}$, \\ Dieudonné Mumba Ngoyi ${ }^{2}$, Papy Mandoko Nkoli ${ }^{2}$, Ange Landela ${ }^{2}$, Pascal Robin Ongoka ${ }^{1}$ and \\ Jean-Maurille Ouamba ${ }^{1}$
}

\footnotetext{
${ }^{1}$ Unité de Chimie du Végétal et de la Vie, Faculté des Sciences et Techniques, Université Marien NGOUABI, BP 69, Brazzaville, République du Congo.

${ }^{2}$ Laboratoire de Parasitologie, Institut National de Recherches Biomédicales, B.P. 1197, Kinshasa, République Démocratique du Congo.

${ }^{3}$ Laboratoire de Biochimie et Pharmacologie, Faculté des Sciences de la Santé, Université Marien NGOUABI BP 69, Brazzaville-Congo.

${ }^{4}$ Laboratoire de Physiologie et Physiopathologie Animales, Faculté des Sciences et Techniques, Université Marien NGOUABI, BP 69, Brazzaville- Congo.
}

Accepted 2 July, 2018

\begin{abstract}
Alstonia boonei De Wild is very cited in ethnobotanical surveys and in literature as an antimalarial plant. In the Republic of Congo, traditional therapists use the decoction of $A$. boonei stem bark to treat Malaria. To verify this information obtained from the traditional therapists, we conducted a phytochemical study, evaluated the antiplasmodial activity and the acute toxicity of the decoction of its stem bark. The phytochemical study revealed the presence of alkaloids, tannins, flavonoids and saponins. It also allowed the extraction of total alkaloids with a yield of $6.33 \pm 0.02 \%$. The antiplasmodial activity evaluated on the strain isolated from patients infected with Plasmodium falciparum was comparable between the decoction $\left(\right.$ IC50 $\left.=111.2 \mu \mathrm{g} \cdot \mathrm{ml}^{-1}\right)$ and the total alkaloids $\left(\mathrm{IC50}=116.4 \mu \mathrm{g} \cdot \mathrm{ml}^{-1}\right)$. This activity is therefore due to alkaloids. The lethal dose $50 \%$ (LD50) is greater than $5000 \mathrm{mg} \mathrm{kg}^{-1}$, the plant is not toxic.
\end{abstract}

Keywords: Alstonia boonei, decoction, phytochemistry, total alkaloids, antiplasmodial, acute toxicity.

*Corresponding author. E-mail: tabunahermeline@gmail.com. Tel: (00242)55559311.

\section{INTRODUCTION}

Malaria is one of eradicated diseases in the developed country, with the exception of a few cases of importation, but it remains one of the most widespread and deadly diseases in the world (WHO, 2013). The World Health Organization (WHO) has reported 214 million cases of malaria worldwide in 2015, with 438.000 deaths. About 3.2 billion people, nearly half of the world's population, are at risk of malaria. However, $85 \%$ of all malaria cases and $90 \%$ of global malaria deaths are concentrated in the African continent (WHO, 2015).
To treat malaria, part of the African population uses traditional medicine (Adebayo and Krettli, 2011; Memvanga et al., 2015; Kodjovi et al., 2017). Africa is rich in biodiversity (UNDP, 2009; Kanouté and Kampmann, 2010, Akaibe et al., 2014), and plant biodiversity is an important source of new molecules of therapeutic interest. The most effective antimalarials are quinine and artemisinin (WHO, 2011, 2013), from the Cinchona calisaya Weed and Artemisia annua L., which are plants used in the traditional Peruvian and Chinese 
pharmacopoeia respectively (Bruneton, 2009).

In addition, drawing on quinine and artemisinin, researchers have been able to synthesize other antimalarials such as chloroquine (Surrey and Hammer, 1946) and artesunate (Chekem and Wierucki, 2006). It is therefore very important to have scientific data on traditional remedies. These scientific data may contribute to the discovery of new antimalarial molecules, when resistance to artemisinin has already been reported (WHO, 2011), the current main compound for the treatment of Plasmodium falciparum malaria (WHO, 2013), the most dangerous species of Plasmodium (Mouchet et al., 2004). The Republic of Congo has a heavy burden of malaria (Moyen et al., 2010, Ntoumi et al., 2013, Koukouikila-Koussounda and Ntoumii, 2016); it is one of the countries with high malaria transmission (WHO, 2016). Combined therapies based on artemisinin or its derivatives (ACT) are used in Congo (KoukouikilaKoussounda et al., 2017; Ndounga et al., 2013), but as in several African countries, in Congo, a portion of the lowincome population has a problem of accessibility to drugs (Trapsida et al., 2010). They use traditional medicine to treat malaria (Nsonde-Ntandou et al., 2005; Gando, 2006).

An ethnobotanical survey was carried out among the traditional therapists in Owando, in the Department of the Cuvette, in the Republic of Congo, in order to collect plants used to treat malaria in that locality. During this ethnobotanical survey, Alstonia boonei De Wild was selected for being the most cited plant by traditional healers. The purpose of our work is to identify the secondary metabolites, to evaluate the antiplasmodial activity and the acute toxicity of the aqueous extract of $A$. boonei stem bark, in order to verify the information obtained from the traditional therapists on this plant.

\section{MATERIALS AND METHODS}

\section{Plant material}

The stem bark of $A$. boonei was collected in October 2015, in Brazzaville (Republic of the Congo), on the edge of the TSIEME river, in the District $\mathrm{N}^{\circ} 7$ named Talangai, and dried for a month at $25^{\circ} \mathrm{C}$, out of the sun. A voucher specimen has been deposited at the herbarium of the Institut des Recherches en Sciences Exactes et Naturelles (IRSEN) under reference number 15786.

\section{Animal material}

The animal material consisted of Swiss albino mice, (males and females) weighing between 17.06 and $24.67 \mathrm{~g}$, reared at the animal house of the Faculty of Science and Technology of the University Marien NGOUABI in standard conditions $\left(25 \pm 5^{\circ} \mathrm{C}, 40\right.$ to $70 \% \mathrm{RH}$, $12 \mathrm{~h}$ light/dark cycle), and fed with standard food with water ad libitum.

\section{Ethnobotanical survey}

The ethnobotanical survey was conducted in November 2014, in
Owando, in the Department of Cuvette, in the Republic of Congo. Using a questionnaire, the traditional therapists were asked about the plants they use in the treatment of malaria. The vernacular name, the part used and the instructions for use of these plants have been collected.

\section{Phytochemical study}

\section{Preparation of the extract}

Twenty grams $(20 \mathrm{~g})$ of plant material powder were added to $200 \mathrm{ml}$ of distilled water. The resulting mixture was refluxed for 40 min in a $500 \mathrm{ml}$ flask. After heating, the mixture is cooled and filtered with a filter paper and the filtrate is evaporated using a Rotavapor at a temperature of $60^{\circ} \mathrm{C}$.

\section{Characterization of secondary metabolites}

The tube reaction method was used. Secondary metabolites were characterized in the decoction, but also in the infused, macerated and organic solvents extracts, by the reactions of stains and precipitations with specific reagents according to conventional methods (Bouquet, 1972).

\section{Determination of total alkaloids}

$20 \mathrm{~g}$ of plant material powder were degreased in $300 \mathrm{ml}$ of petroleum ether for $3 \mathrm{~h}$. After filtration, the grounds were dried at room temperature $\left(25 \pm 5^{\circ} \mathrm{C}\right)$ and macerated for $3 \mathrm{~h}$ in $200 \mathrm{ml}$ of distilled water acidified with $2 \mathrm{ml}$ of concentrated sulfuric acid. This operation was repeated until a negative alkaloid identification test was obtained with the MAYER reagent. The various macerates were mixed and obtained mixture was basified with $10 \%$ sodium carbonate up to $\mathrm{pH}=9$. The alkalized solution was then extracted successively with $200 \mathrm{ml}$ of chloroform, until obtaining a negative alkaloid identification test with MAYER reagent. The organic phase was evaporated in Rotavapor to obtain total alkaloids (Bruneton, 2009).

\section{Study of antiplasmodial activity}

\section{Collection of infected blood}

The study of antiplasmodial activity was carried out at the National Institute of Biomedical Research (I.N.R.B.), which is a National Public Health Laboratory of the Democratic Republic of Congo (DRC). The antiplasmodial activity of the decoction and total alkaloids was evaluated, by optical micro - test method, on parasitized blood, by Plasmodium falciparum, taken from a 2 year old child, at the Kingasani Hospital Center in Kimbanséké commune in Kinshasa. This area is known to have a high transmission of resistant Plasmodium falciparum malaria. At the time of blood collection, the child had the following characteristics: fever $\left(38^{\circ} \mathrm{C}\right)$, no previous taken of antimalarial, positives rapid diagnostic test (RDT) and thick blood smear with $1.3 \%$ of Plasmodium falciparum parasitaemia.

\section{Realization of the test}

Decoction solutions and total alkaloids were prepared with initial concentrations of $10.000 \mu \mathrm{g} \cdot \mathrm{ml}^{-1}$, then were impregnated into triplicate on the 96-well multiwell plates containing methanol at 50 $\mu l$ per well. The impregnation on the plates was done with a dilution 
of half to half, wells per well, varying the initial concentrations of these solutions from 10.000 to $4.88 \mu \mathrm{g} \cdot \mathrm{ml}^{-1}$. Quinine $(500 \mathrm{mg} / 2 \mathrm{ml})$ and artesunate $(120 \mathrm{mg} / 12 \mathrm{ml})$ were used as reference compounds. These compounds were also diluted to concentrations of $6.10 \mu \mathrm{g} \cdot \mathrm{ml}^{-1}$ for quinine and $0.244 \mu \mathrm{g} \cdot \mathrm{ml}^{-1}$ for artesunate. The plates impregnated with the solutions were stored at $37^{\circ} \mathrm{C}$ in a $\mathrm{CO}_{2}$ incubator for $24 \mathrm{~h}$.

After preparation of the plates, the culture medium was prepared by mixing $20 \mathrm{ml}$ of RPMI 1640 containing $25 \mathrm{mM}$ hepes-L-glutamine buffer with $1.160 \mathrm{ml}$ of $3.6 \% \mathrm{NaHCO}_{3} ; 2 \mathrm{ml}$ of the solution thus obtained were substituted with $2 \mathrm{ml}$ of the serum of the healthy human blood. This culture medium was mixed with $322.5 \mu \mathrm{l}$ of the parasitized blood and homogenized; this solution containing the parasitized blood was distributed in the plates at a rate of $50 \mu \mathrm{l} /$ well. The plates were covered, then placed in a jar that was tightly closed. To subtract oxygen and to enrich $\mathrm{CO}_{2}$ in the jar, a candle was burnt. Whole was then kept in an incubator for $48 \mathrm{~h}$. Then, the thick drops were made from each well. Thick droplet slides were read using an optical microscope (Primo-Star) to determine parasitaemia and calculate the percentage of parasite growth inhibition.

\section{Acute toxicity study}

The acute toxicity study of the decoction of bark of $A$. boonei was conducted according to the method described in the OECD Test Guideline No. 423 (OECD, 2011). Three lots of three (3) Swiss albino mice were formed. After three (3) days of acclimation, mice were fasted for $24 \mathrm{~h}$ before the experiment. These animals received orally the following doses:

Lot 1: control mice receiving distilled water at the dose of $20 \mathrm{ml} . \mathrm{kg}$ 1 ;

Lot 2: mice treated with the extract at the dose of $2000 \mathrm{mg} \cdot \mathrm{kg}^{-1}$;

Lot 3: mice treated with the extract at the dose of $5000 \mathrm{mg} \cdot \mathrm{kg}^{-1}$.

After administration of the aqueous extract, animals were observed during:

- $3 \mathrm{~h}$ to look for a possible change in their general condition (aggression, tail condition, pain sensitivity, mobility and stool condition):

- $48 \mathrm{~h}$ to assess mortality;

- 14 days to evaluate the effect of this extract on water intake, food and body weight of mice.

\section{Statistical analysis}

Inhibitory concentrations $50 \%$ of our extracts were determined using the Origin Pro 8.5 software. Percentage parasite growth inhibition was calculated by the following formula:

Inhibition $\%=100 \%-\left(\frac{\text { average of mature parasites }}{\text { average of youger parasites }}\right) .100 \%$

\section{RESULTS}

\section{Ethnobotanical survey}

The results of the ethnobotanical survey are presented in Table 1. Eight (8) plants belonging to six families were cited by consulted traditional therapists in this study: Apocynaceae (2), Rubiaceaes (2), Costaceae (1),
Aricacaee (1), Euphorbiaceae (1) and Phyllanthaceae (1). A. boonei was the most cited (80\%). For these traditional therapists, that plant is very effective in the treatment of malaria.

\section{Phytochemical study}

\section{Characterization of secondary metabolites}

Results of the phytochemical study are presented in Table 2. The chemical families found in the aqueous extract of $A$. boonei bark are alkaloids, tannins, flavonoids and saponins.

\section{Determination of total alkaloids}

After a series of three extractions, the quantitative analysis of alkaloids in the bark of $A$. boonei yielded an average mass of $1.2 \mathrm{~g}$ of total alkaloids corresponding of $6.33 \pm 0.02 \%$, from $20 \mathrm{~g}$ of plant material powder.

\section{Antiplasmodial activity}

Reading the slides under the microscope and calculating the percentages of inhibition made it possible to obtain the results presented in Table 3 . This table shows the different concentrations of the aqueous and alkaloid extracts, and their inhibition percentages. Inhibitory concentrations 50 of our extracts were $111.2 \mu \mathrm{g} \cdot \mathrm{ml}^{-1}$ for the decoction and $116.4 \mu \mathrm{g} \cdot \mathrm{ml}^{-1}$ for the alkaloid extract.

\section{Acute toxicity study}

Of all the visible signs sought (aggression, tail state, sensitivity to pain, mobility and stool condition), only the reduction in mobility was observed on the day of administration of the extract, in the mice that received the extract at a dose of $5000 \mathrm{mg} \cdot \mathrm{kg}^{-1}$. One death was recorded in lot 3 on the 6th day of the experiment. Figures 1, 2 and 3 show changes in water intake, food consumption, and body weight, respectively, during the 14 days of the experiment.

The observation of Figure 1 shows that the amount of water taken by these animals is greater for lot 3 ; it increased during the three days following the administration of the aqueous extract of the plant. After three days, this water intake decreased and increased alternately until the end of the experiment. At the level of lots 1 and 2, the water intake has undergone alternately a decrease and an increase from the beginning to the end of the experiment.

Figure 2 shows large food consumption for the mice of lot 3 after the administration of the aqueous extract of the plant. This consumption is greater on the second day. 
Table 1. Ethnobotanical survey of plants used to treat malaria in Owando.

\begin{tabular}{lllll}
\hline Vernacular names & Scientific names & Family & Part of the plant used & Method of preparation \\
\hline Ekaga (K), Ekaha (M) & Eremospatha cabrae de Wild & Aricaceae & Bark & Decoction \\
Kongo bololo (L) & Morinda morindoides (Bak). Milne-Red & Rubiaceae & Leaf, stems & Decoction \\
Motsako (K) & Costus afer Ker-Gawl & Costaceae & Leaves & Decoction \\
Odjoudjougou (K) & Sarcocephalius latifolius J.E. Smith & Rubiaceae & Root & Decoction \\
Okocha (K) & Manniphyton fulvum Mull. Arg. & Euphorbiaceae & Bark & Decoction, maceration \\
Okouga (K) & Alstonia boonei De Wild & Apocynaceae & Bark & Decoction \\
Onguanguina (M) & Hymenocardia acida Tul. & Phyllanthaceae & Root & Decoction \\
Oté (K) & Rauvolfia manii Stapf & Apocynaceae & Bark & Decoction \\
\hline
\end{tabular}

(K): Kouyou, (M): Makoua, (L): Lingala.

Table 2. Chemical screening of the various extracts of $A$. boonei.

\begin{tabular}{lcl}
\hline \multirow{2}{*}{ Chemical families } & \multicolumn{2}{c}{ Results } \\
\cline { 2 - 3 } & Decoction & Infused (I), macerated (M) and solvent extracted (S) \\
\hline Alkaloids & + & $+(\mathrm{M})$ \\
Tannins & + & $+(\mathrm{I})$ \\
Flavonoids & + & $+(\mathrm{I})$ \\
Sterols and tri terpenes & - & $-(\mathrm{S}-$ Ether $)$ \\
Leuco anthocyanins & - & $-(\mathrm{I})$ \\
Anthracenics free & - & $-(\mathrm{S}-$ Chloroform) \\
Coumarins & - & $+(\mathrm{S}-$ Ethanol) \\
Saponins & + & $+(\mathrm{M})$ \\
\hline
\end{tabular}

+: Positive test; -: Negative test; M: macerated; I: infused; S: solvent extract.

Table 3. Percentage inhibition of parasite growth.

\begin{tabular}{lcccccccccccc}
\hline I.C. & $\mathbf{1 0 0 0 0}$ & $\mathbf{5 0 0 0}$ & $\mathbf{2 5 0 0}$ & $\mathbf{1 2 5 0}$ & $\mathbf{6 2 5}$ & $\mathbf{3 1 2 . 5}$ & $\mathbf{1 5 6 . 2 5}$ & $\mathbf{7 8 . 1 2 5}$ & $\mathbf{3 9 . 1 0}$ & $\mathbf{1 9 . 5 3}$ & $\mathbf{9 . 7 7}$ & $\mathbf{4 . 8 8}$ \\
\hline I.P.(D) & 100 & 98.99 & 95.65 & 88.26 & 72.67 & 60.765 & 52.23 & 44.32 & 35.51 & 22.22 & 11.67 & 1.21 \\
I.P.(TA) & 100 & 100 & 99.53 & 94.74 & 82.65 & 65.24 & 56.70 & 43.712 & 33.82 & 29.34 & 15.94 & 5.20 \\
\hline
\end{tabular}

IC: Inhibitory concentration, I.P.: Inhibition percent, T.A.: Total alkaloids, D: Decoction

$0.244 \mu \mathrm{g} \cdot \mathrm{ml}^{-1}$ of artesunate $=\mid 72.81 \% \mathrm{IC}$ and $6.10 \mu \mathrm{g} \cdot \mathrm{ml}^{-1}$ of quininel $=82.10 \% \mathrm{IC}$.

With lot 2, food consumption has alternated a decrease and an increase from beginning to the end of the experience. In lot 1 , food consumption decreased from the beginning to the 6th day before to increase and decrease alternately until the end of the experiment.

Figure 3 indicates that the change in body mass of animals is negligible in lots 1 and 2 after the second day. However, this change in body weight is increasing in lot 3 . Water intake and food consumption in lot 3 results in weight gain.

\section{DISCUSSION}

\section{Ethnobotanical survey}

A. boonei was the most cited plant by the traditional therapists during our ethnobotanical survey. In the literature, $A$. boonei is also cited as an antimalarial by many authors (Iwu, 2014, Adjanohoun et al., 1988). The other listed plants are also mentioned in the literature as an antimalarial: they are: Hymenocardia acida (Schmelzer et al., 2008), Sarcocephalus latifolius (N'Guessan et al., 2009), Manniphyton fulvum (Dibong et al., 2011), Morinda morindoides (Zirihi et al., 2010, Tsabang et al., 2017) and Costus afer (Iwu, 2014). On the other hand, we did not find bibliographical references evoking the use of Rauvolfia manii and Eremospatha cabrae in the treatment of malaria.

\section{Phytochemical study}

\section{Characterization of secondary metabolites}

We were interested in the decoction because the 


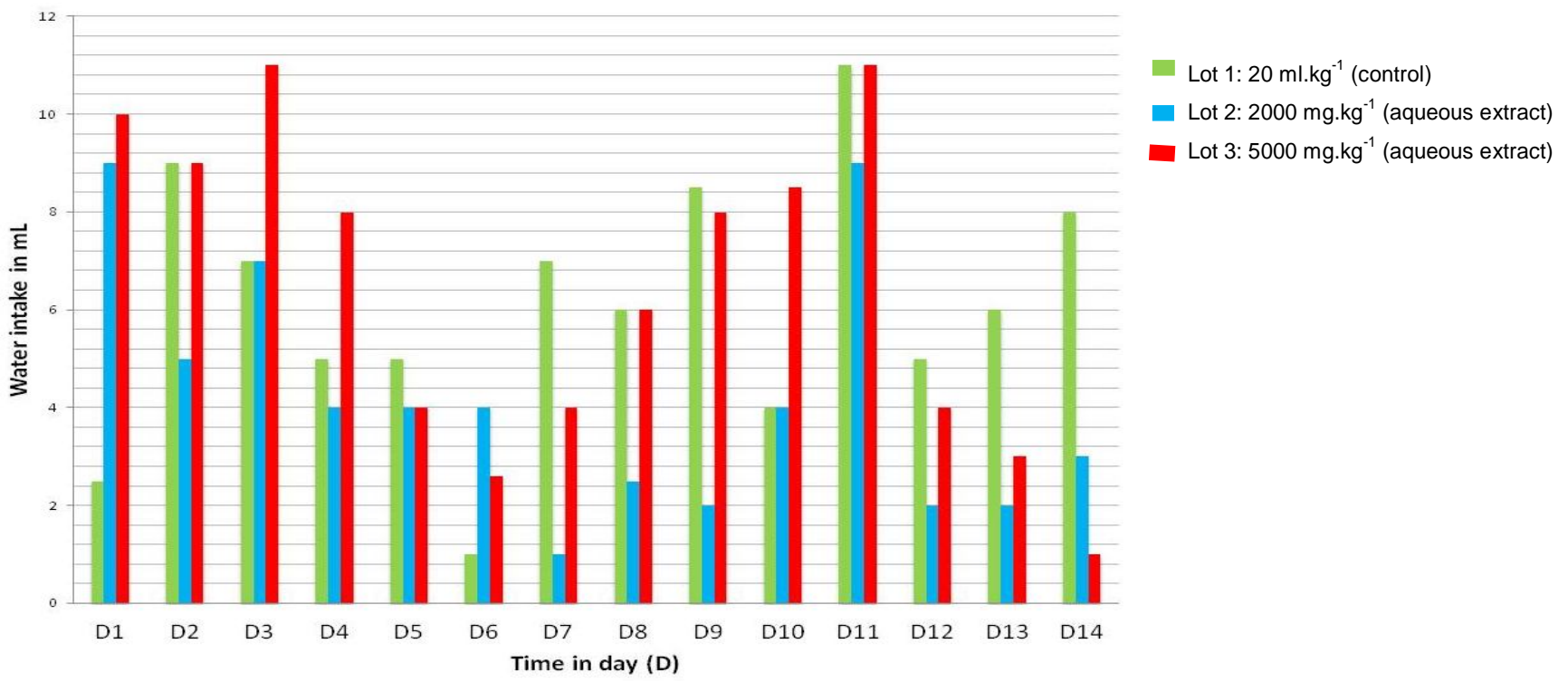

Figure 1. Effects of Alstonia boonei De Wild stem bark aqueous extract in water. Results expressed on average $\mathrm{n}=3$.

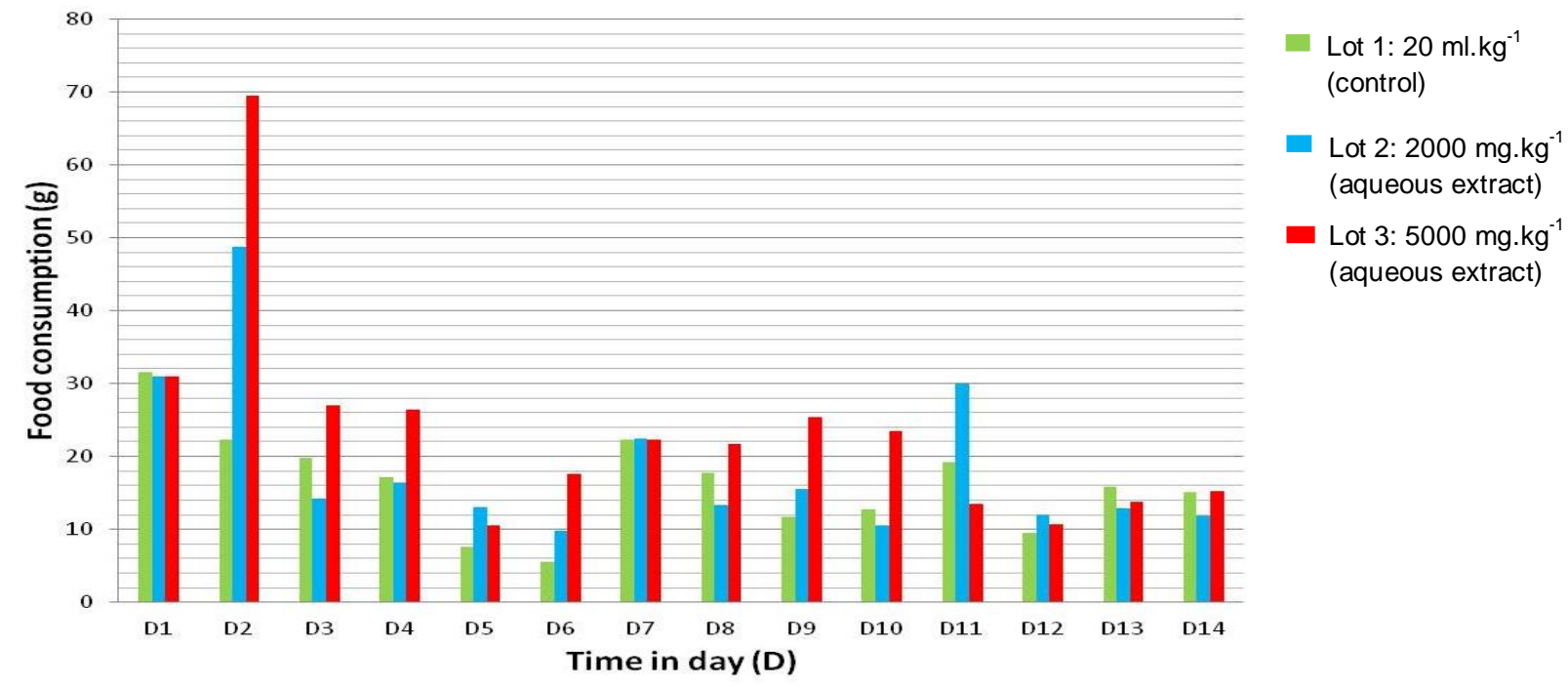

Figure 2. Effects of Alstonia boonei De Wild stem bark aqueous extract in food consumption. Results expressed on average, $n=3$.

traditional therapists use this form of preparation in the treatment of malaria in traditional medicine. The phytochemical study allowed the characterization of alkaloids, tannins, flavonoids and saponins in the decoction of stem bark of $A$. boonei. The flavonoid characterization test gave an orange-yellow color characteristic of flavones. Free sterols and tri-terpenes, leuco anthocyanins and anthracenics were not detected in the various extracts preparation. Coumarins were identified in the ethanolic extract, but not in the decoction. In the literature, Fofana (2004) has also revealed alkaloids, tannins, flavonoids and saponins $A$. boonei stem bark aqueous extract recolted in the region of Abidjan in Ivory Coast (Fofana, 2004). Alkaloids, saponins and tannins were also observed in the ethanolic extract of $A$. boonei leaves by Dibua et al. (2013) and Olayinka and Maganda (2015). Dibua et al. (2013) also found flavonoids in the ethanol extract of $A$. boonei leaves.

\section{Determination of total alkaloids}

The yield of $6.33 \pm 0.02 \%$ that we obtained is greater than the following values $(0.0436,0.0430,0.0318,0.0196$ 


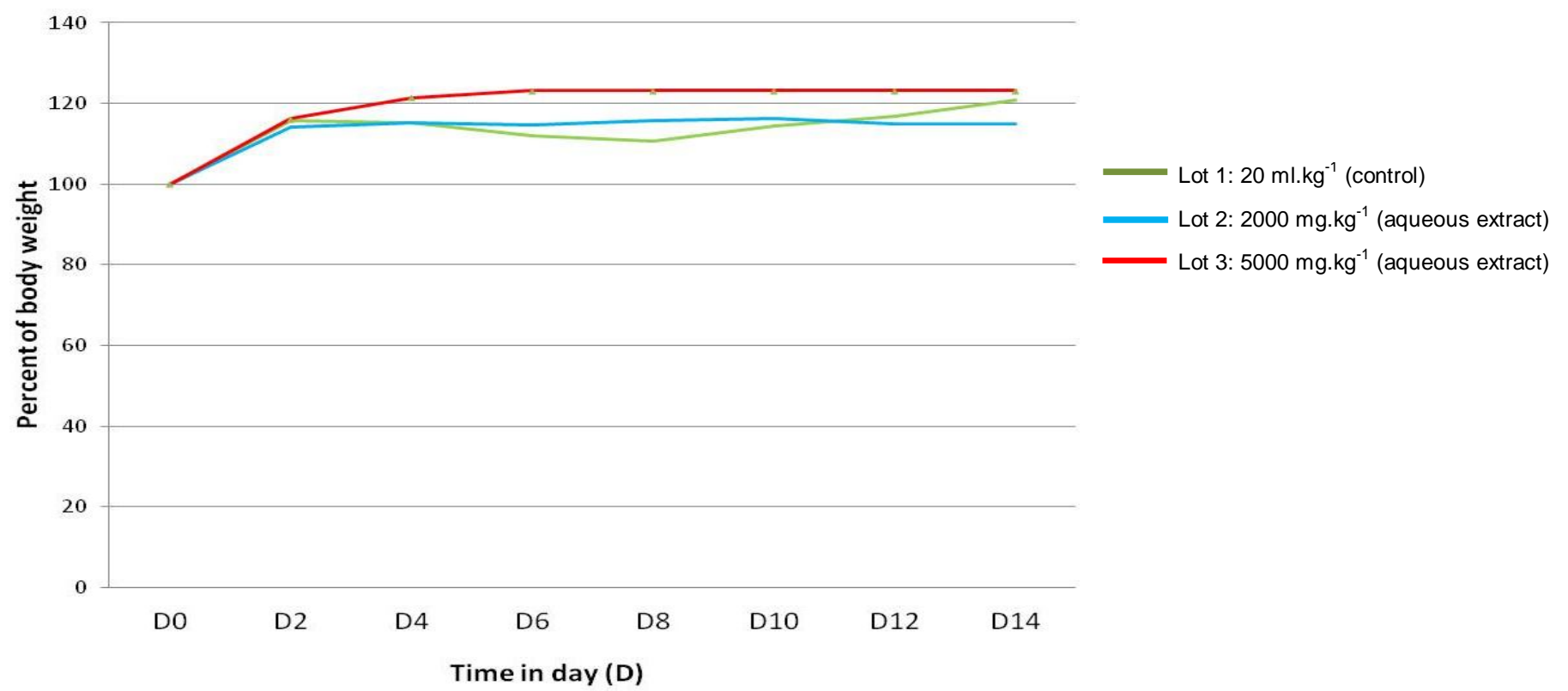

Figure 3. Effects of Alstonia boonei De Wild stem bark aqueous extract in weight gain of mice. Results expressed on average $\mathrm{n}=3$.

and $0.0174 \%$ ), which represent the yields obtained by Kémajou et al. (2012), on the ethanolic extract of $A$. boonei bark collected in Zemengoué village in Cameroon and dried at different temperatures. The two solvents used for the preparation of these extracts, not the same polarity and the extraction procedure used, are not the same, which explains the difference observed.

\section{Antiplasmodial activity}

The antiplasmodial activity of the aqueous extract (IC50 = $111.2 \mu \mathrm{g} . \mathrm{ml}^{-1}$ ) is comparable to that of the total alkaloids $\left(\right.$ IC50 $\left.=116.4 \mu \mathrm{g} \cdot \mathrm{ml}^{-1}\right)$. These results suggest that the antiplasmodial activity of $A$. boonei is related to the presence of alkaloids in this plant. These two extracts have antiplasmodial activities lower than those of the reference molecules, for each IC50 were estimated to be lower than their lowest tested concentrations of 6.10 $\mu \mathrm{g} . \mathrm{ml}^{-1}$ for Quinine with $82.1 \%$ inhibition and $0.244 \mu \mathrm{g} \cdot \mathrm{ml}^{-}$

for artesunate with $72.81 \%$ inhibition. The $50 \%$ inhibitory concentrations obtained with our two extracts of $A$. boonei, are in the range of those obtained by Sarpong $\left(\right.$ IC50 > $\left.100 \mu \mathrm{g} \cdot \mathrm{ml}^{-1}\right)$ with the ethanolic and ether extracts of the stem bark, of this plant on Plasmodium falciparum strains (Sarpong et al., 2016). In the literature, Musuyu et al. (2012) reported an IC50 > $64 \mu \mathrm{g} \cdot \mathrm{ml}^{-1}$, for the aqueous extract and Zirihi et al. (2005) an IC50>50 $\mu \mathrm{g} \cdot \mathrm{ml}^{-1}$ for the ethanolic extract of $A$. boonei stem bark on Plasmodium falciparum strains.

The low antiplasmodial activity observed in vitro for our two extracts $\left(\mathrm{IC50}=111.2 \mu \mathrm{g} \cdot \mathrm{ml}^{-1}\right.$ and $\mathrm{IC} 50=116.4$ $\mu \mathrm{g} \cdot \mathrm{ml}^{-1}$ ) does not implicate the use of the plant in the treatment of malaria reported by the traditional therapists. The MALARIAL, for example, marketed in Mali, is a phyto antimalarial drug that has a $50 \%$ inhibitory concentration of $600 \mu \mathrm{g} \cdot \mathrm{ml}^{-1}$ (Gasquet et al., 1993). Indeed, the molecules constituting an extract may have in vivo interactions that do not occur in vitro.

\section{Acute toxicity study}

Compared to the protocol used (OECD 2001), we can say that the aqueous extract of the bark of $A$. boonei has a lethal dose of $50 \%$ (LD 50) estimated higher than 5000 $\mathrm{mg} \cdot \mathrm{kg}^{-1}$. Therefore, this plant is not toxic. This result is similar to that obtained by Nkono, for the study of the acute toxicity of the aqueous extract of the stem bark of A. boonei collected at Ombessa in Cameroon (Nkono et al., 2014). Our results are also similar to those obtained by lyiola et al. (2011) and Dibua et al. (2013) on the $A$. boonei leaves ethanolic extract collected in Shagari and Nsukka (Nigeria).

\section{CONCLUSION}

Our study has shown that $A$. boonei plant is mostly used in the treatment of Malaria in traditional medicine, in the department of Cuvette in Congo. Its stem bark decoction extract is not toxic according to the OECD, with a $50 \%$ lethal dose that is greater than $5000 \mathrm{mg} \cdot \mathrm{kg}^{-1}$. The plant is rich in several secondary metabolites. Its in vitro antiplasmodial activity is low and related to alkaloids chemical group. 


\section{REFERENCES}

Adebayo JO, Krettli AU, 2011. Potential antimalarials from Nigerian Plants: A review. J Ethnopharmacol, 133(2): 289-302.

Adjanohoun E, Ahyi A, Ake Assi L, Baniakwa J, Chibon P, Cusset G, Doulou V, Enzanza A, Eymê J, Goudote E, Keita A, Mbemba C, Mollet J, Moutsambote JM, Mpati JB et Sita P, 1988. Contribution aux études ethnobotaniques et floristiques en République Populaire du Congo. ACCT, Paris, $605 \mathrm{p}$.

Akaibe D, Masens Da-Musa B, Katunda LWO, Tiarina MJ, Sondi KM, Kihosa J, Kambamba M, Mpupu B, 2014. Etat des lieux de la biodiversité dans la RD Congo. Centre de Surveillance de la Biodiversité, $381 \mathrm{p}$.

Bouquet A, 1972. Plantes médicinales du Congo-Brazzaville. ORSTOM, Paris, P 8-12.

Bruneton J, 2009. Pharmacognosie - Phytochimie - Plantes médicinales. TEC et DOC - Lavoisier, Paris. $4^{\mathrm{e}}$ edition, p. $755-759$, 1178-1184, 945-951.

Chekem L, Wierucki S, 2006. Extraction de l'artémisinine et synthèse de ses dérivés: artésunate et arthéméther. Med Trop, 66(6): 602-605.

Dibong SD, Mpondo Mpondo E, Ngoyé A, Priso RJ, 2011. Modalities of exploitation of medicinal plants in Douala's region. Afr J Food Nutr, 1(2): 67-73.

Dibua UME, Okeke CC, Ugwu C, Kenechukwu FC and Okorie A, 2013. In vivo antimalarial and cytotoxicity activity of ethanolic stem bark of Petersianthus macrocarpus and leaf of Astonia boonei in experimental mice model. Int J Curr Microbiol Appl Sci, 2(12): 354368.

Fofana $S, 2004$. Exploration biochimique sur le pouvoir immunogène de trois plantes en Côte d'lvoire: Alstonia boonei (Apocynaceae), Mitragyna ciliata (Rubiaceae), Terminalia Catappa (Combretaceae). Thèse de Doctorat, Université de BAMAKO, $123 \mathrm{p}$.

Gando A, 2006. Politique nationale de médecine traditionnelle. Ministère de la santé et de la population, République du Congo, $17 \mathrm{p}$.

Gasquet M, Delmas F, Timon-David P, Keita A, Guindo M, Nkoita N, Diallo D, Doumbo O, 1993. Evaluation in vitro and in vivo of a traditional antimalarial : Malarial 5. Fitoterapia, 64(5): 423-426.

Iwu MM, 2014. Handbook of African medicinal plants. $2^{\mathrm{e}}$ Edition, Amazon France. p 137.

Iyiola AO, Tijani AY, Lateef KM, 2011. Antimalarial activity of ethanolic stem bark extract of Alstonia boonei in mice. As J Biol Sci, 4(3): 235243.

Kanouté $S$ and Kampmann D, 2010. Biodiversity atlas of West Africa. Volume III, Ivory Coast, Abidjan and Frankurt / Main, 560 p.

Kémajou $A, M b a$ L, Bagda AA, 2011. Effet du séchage sur les principes actifs des plantes médicinales: cas des alcaloides totaux des écorces de Alstonia boonei De Wild, une plante antipaludéenne. Nat Tech, 7: 62-66.

Kodjovi A, Holaly E, Gbekley, Karou SD, Kokou A, and Simpore S, 2017. Antiplasmodial activity of medicinal plants from West Africa: Review of the literature. Int J Innov Sci Res, 28(2): 121-129.

Koukouikila-Koussounda F, Ntoumi F, 2016. Epidemiological research of malaria in the Republic of Congo. Malar J, 15: 598.

Koukouikila-Koussounda F, Jeyaraj S, Nguetse CN, Nkonganyi CN, Kokou KC, Etoka-Beka MK, Ntoumi F, Velavan TP, 2017. Molecular monitoring of drug resistance by Plasmodium falciparum in the Republic of Congo four and nine years after the introduction of artemisinin combination therapy. Malar J, 16: 155.

Memvanga PB, Tona GL, Mesia GK, Lusakibanza MM, Cimanga RK, 2015. Antimalarial activity of medicinal plants from the Democratic Republic of Congo: A review. J Ethnopharmacol, 169(1): 76-98.

Mouchet J, Carnevale P, Coosemans M, Julvez J, Manguin S, RichardLenoble D and Sircoulon J, 2004. Biodiversité du Paludisme dans le monde. John Libbey Euro Text, Paris, p 38,120-123, 312.

Moyen G, Mbika CA, Kambourou J, Oko A, Mouko A, Obengui, 2010. Paludisme grave de l'enfant à Brazzaville. Med Afr Noire, 57(2): 113 $-116$.

Musuyu MD, Fruth BI, Nzunzu Lami J, Mesia GK, Kambu OK, Tona GL, Cimanga Kanyanga R, Cos P, Maes L, Apers S, Pieters L, 2012. In vitro antiprotozoal and cytotoxic activity of 33 ethnopharmacologicaly selected medicinal plants from Democratic Republic of Congo. J Ethnopharmacol, 141(1): 301-308.
N'guessan K, Trabi FH, Koné MW, 2009. Ethno-pharmacological study of antimalarial plants used in traditional medicine at Abbey and Krobou d'Agboville (Ivory Coast). Ethnopharmacologia, 42: 42-50.

Ndounga M, Mayengue PI, Casimiro PN, Loumouamou D, Basco LK, Ntoumi F, Brasseur $P$, 2013. Artesunate-amodiaquine efficacy in Congolese children with acute uncomplicated falciparum malaria in Brazzaville. Malar J, 12: 53.

Nkono BNLY, Sokeng SD, Dzeufiet Djomeni PD, Kamtchouing P, 2014. Antihyperglycemic and antioxydant properties of Alstonia boonei de wild (Apocynaceae) stem bark aqueous extract in dexamethasoneinduced hyperglycemic rats. Int J Diab Res, 3(3): 27-35.

Nsonde-Ntandou GF, Ndounga M, Ouamba JM, Gbeassor M, EtouOssibi A, Ntoumi F, Abena AA, 2005. Enquête ethnobotanique: screening chimique et efficacité thérapeutique de quelques plantes utilisées contre le paludisme en medicine traditionnelle à Brazzaville. Phytothérapie, 3(1): 13-18.

Ntoumi F, Vouvoungui JC, Ibara R, Landry M, Sidibé A, 2013. Malaria burden and case management in the Republic of Congo: limited use and application of rapid diagnostic test results. BMC Pub Health, 13: 135.

Olayinka FO, Maganda V, 2015. In vivo activity of ethanolic extract of Alstonia Boonei leaves against Plasmodium Berghei in mice. J World Hol Sust Dev, 1(4): 60-68.

Organisation for Economic Cooperation and Development (OECD 423), 2001. Guideline for evaluation of chemicals. Acute Oral toxicity Acute Toxic Class Method. $14 \mathrm{p}$.

Sarpong LM, Sarpong FM, Amponsah IK, 2016. Antiplasmodial activity of the leaves and stem bark Ofcarapa procera and Alstonia boonei. Scho Res Libr - Der Pharm Let, 8(3): 116-122.

Schmelzer GH, Schmelzer GH and Gurib-Fakim A, 2008. Médicinal plant 1. Amazon, France, p 213, 380.

Surrey AR, Hammer HF, 1946. Some 7-substituted 4-amino-quinoline derivatives. J An chem Soc, 68: 113-116.

Trapsida JM, Mankele R, Nzébélé $P$, Okono G, 2010. Problem of the access of Brazzaville city population to artemisinin based combinations. Afr Health Mon, 12: 40-46.

Tsabang N, Atsano A, Tsambang JET, Donfagsiteli N, Yedjou CG, TchindaThiabo A, Agbor GA, and Tchounwou PB, 2017. Medicinal uses and natural availability of three plant species in selected Ecosystems in Cameroun. J Anal Pharm Res, 4(4): 110-118.

United Nations Development Program (UNDP), 2009. Fourth National on Biodiversity. UNDP- Republic of Congo- World Environment Fund $117 \mathrm{p}$.

World Health Organization (WHO), 2011. Guidelines for the treatment of Malaria, $2^{\text {nd }}$ Edition, p. $16-17$

World Health Organization (WHO), 2013. Management of severe Malaria. Practical guide, $3^{\text {rd }}$ Edition, p 14, 72 - 73.

World Health Organization (WHO), 2013. World Malaria Report. http://www.who.int/malaria/publications/word_malaria_repport_2013/. August 24, 2017.

World Health Organization (WHO), 2015. Report on Malaria in the World. http://www.who.int/features/factfiles/malaria/fr/. February 19, 2016

World Health Organization (WHO), 2016. Report on Malaria in the World. http//www.who.int/malaria/publication/countryprofiles/profilr_cog_en. August 24, 2017.

Zirihi GN, Mambu L, Guédé Guina F, Bodo B, Grellier P, 2005. In vitro antiplasmodial activity and cytotoxicity of 33 West African plants used for treatment of malaria. J Ethnopharmacol, 98(3): 281-285.

Zirihi GN, N'guessan K, Etien Dibié T and Grellier P, 2010. Ethno pharmacological study of plants used to treat malaria in traditional medicine, by bête populations of ISSIA (Côte d'Ivoire). J Pharm Sci Res, 2(4): 216-227.

Citation: Ntalani $\mathrm{H}$, Akouala Bouanga MSC, Nsonde Ntanou GF, Mumba Ngoyi D, Mandoko Nkoli P, Landela A, Ongoka PR, Ouamba JM, 2018. Phytochemical study, antiplasmodial activity and acute toxicity of the aqueous extract of the stem bark of Alstonia boonei De Wild. Adv Med Plant Res, 6(3): 33-39. 